Mykhaskova Maryna. Effectiveness of implementation of the method pedagogical system of forming the experience of musicpedagogical activity of the future music art teachers. Journal of Education, Health and Sport. 2019;9(11): 386-393. eISSN 2391-8306. DOI http://dx.doi.org/10.12775/JEHS.2019.09.11.036

https://apcz.umk.pl/czasopisma/index.php/JEHS/article/view/JEHS.2019.09.11.036

http://dx.doi.org/10.5281/zenodo.3713434

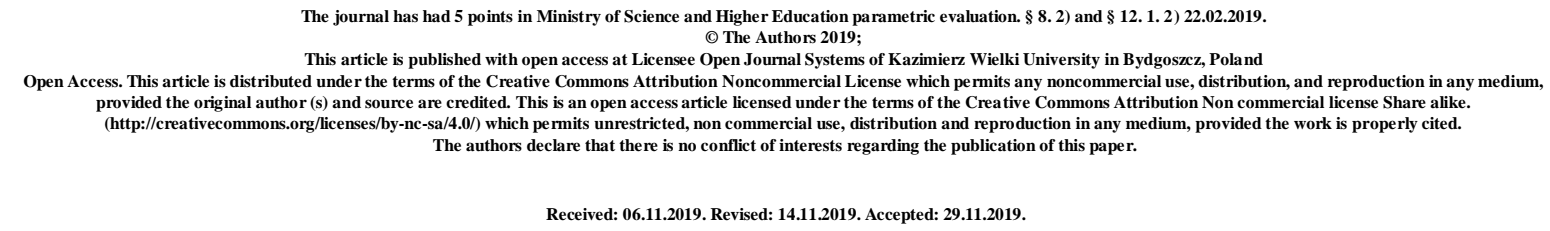

UDK 37.091.12.011.3-051:78

\title{
EFFECTIVENESS OF IMPLEMENTATION OF THE METHOD PEDAGOGICAL SYSTEM OF FORMING THE EXPERIENCE OF MUSIC-PEDAGOGICAL ACTIVITY OF THE FUTURE MUSIC ART TEACHERS
}

\author{
Maryna Mykhaskova \\ Khmelnytskyi Humanitarian-Pedagogical Academy
}

Candidate of pedagogical sciences, Assistant Professor,

Head of the department of theory and methods of music art, orcid.org / 0000-0003-1248-3903

(Khmelnitsky, Ukraine) chudo43@gmail.com

\section{Abstract}

The article analyzes of forming the experience of music-pedagogical activity of the future teacher of music art. Diagnosis of the experience of music-pedagogical activity of the future music art teacher by the criteria (completeness, systematic and strength of knowledge based on the formedness of professional-pedagogical and innovative thinking; the level of formedness of experience of using the methods of music-pedagogical activity; presence of emotional-value attitude to music-pedagogical activity; intensification of communication on the basis of joint interaction of the participants of music-pedagogical activity; level of ability to predict, analyze, control and adjust music-pedagogical activity; originality of creative experience in various types of music-pedagogical activity) and indicators allows to evaluate the level of its formedness, to predict approaches, conditions and directions of improving the effectiveness of professional training of pedagogues-musicians. 
The feasibility of the chosen system of training of the future teachers of music art has been grounded. It is based on the structural and functional components of the process, provides for the realization of clearly defined principles, conditions, methodological and methodical principles. It is determined that the introduction of the special course "Art Workshop" allows improving the results of professional training of the future pedagoguesmusicians. The offered course includes lectures, practical classes, seminars, independent work, teaching and control methods, approximate evaluation of students' educational activities by rating system, distribution of points received by students in the course of mastering the special course "Art Workshop", the scale of assessment according to the national and ECTS system, methodological support of the special course, recommended literature, information resources of the discipline.

Key words: system; experience of music-pedagogical activity; professional training of the future teacher of music art.

\section{РЕЗУЛЬТАТИВНІСТЬ ПРОВАДЖЕННЯ МЕТОДИКИ ФОРМУВАННЯ ДОСВІДУ МУЗИЧНО-ПЕДАГОГІЧНОЇ ДІЯЛЬНОСТІ МАЙБУТНІХ УЧИТЕЛІВ МУЗИЧНОГО МИСТЕЦТВА}

\section{Марина Михаськова}

\section{Хмельницька гуманітарно-педагогічна академія}

кандидат педагогічних наук, доцент, завідувач кафедри теорії та методики музичного мистецтва orcid.org / 0000-0003-1248-3903

(Хмельницький, Україна) chudo43@gmail.com

У статті проводиться аналіз формування досвіду музично-педагогічної діяльності майбутнього вчителя музичного мистецтва. Діагностика досвіду музичнопедагогічної діяльності майбутнього вчителя музичного мистецтва за критеріями (повнота, системність та міцність знань на основі сформованості професійнопедагогічного та інноваційного мислення; ступінь сформованості досвіду здійснення способів музично-педагогічної діяльності; наявність емоційно-ціннісного ставлення до музично-педагогічної діяльності; активізація спілкування на основі спільної взаємодії 
учасників музично-педагогічної діяльності; рівень володіння вміннями прогнозувати, аналізувати, контролювати i коригувати музично-педагогічну діяльність; оригінальність творчого досвіду в різноманітних видах музично-педагогічної діяльності) та показниками дає можливість оцінити рівень іiі сформованості, спрогнозувати підходи, умови та напрями підвищення ефективності професійної підготовки педагогів-музикантів.

Обгрунтовується доцільність обраної системи підготовки майбутніх вчителів музичного мистецтва, яка базується на структурних і функціональних компонентах процесу, передбачає реалізацію чітко визначених принципів, умов, методологічних і методичних засад. Визначено, що впровадження спецкурсу «Мистецький практикум» дозволяє покращити результати професійної підготовки майбутніх педагогівмузикантів. Запропонований курс включає лекційні теми, практичні заняття, семінарські заняття, самостійну роботу, методи навчання та контролю, орієнтовне оцінювання видів навчальної діяльності студентів за рейтинговою системою, розподіл балів, які отримують студенти в процесі засвоєння спецкурсу «Мистецький практикум», шкалу оцінювання за національною та ECTS системою, методичне забезпечення спецкурсу, рекомендовану літературу, інформаційні ресурси дисципліни.

Ключові слова: система; досвід музично-педагогічної діяльності; професійна підготовка майбутнього вчителя музичного мистецтва.

Statement of a problem. In the formation conditions of new Ukraine, cultural and spiritual revival of the people, the professional training problem of future teacher gets paramount value. At the same time the state level of higher education demands training of the expert who meets world standards and will be rather competitive in practice of pedagogical activity. That is why essential and a relevant task of professional education is to create experience formation of music-pedagogical activity for future music art teacher in pedagogical system.

Analysis of researches. In scientific literature this phenomenon was considered from the different points and studied by many scientists. O. Rostovsky [2], V. Cherkasov [6] and others studied theoretical and methodological foundations of general pedagogical training of music teacher. In the sphere of performing activity of musicians the problem of development of musical and pedagogical experience was covered in A. Rudnitskaya [3] and O. Hlebnikova [4] works; experience of the music art teacher in the system of continuous pedagogical education was sdudied by N. Popovic [1]. However, researches of these and other scientists 
are not directed to studying, streamlining and synthesising of experience of music pedagogical activity of future music art teacher in the system of professional education.

Article purpose - to disclose the results of introduction of an experience formation technique of music-pedagogical activity of future music art teachers in the course of professional training in higher education institutions.

Statement of the main material. According to inquiries of modern Ukrainian music education we defined a system and a model of experience formation of music-pedagogical activity for future music art teacher. These predicted receiving a product that implements the ways and means of performance the objectives of musical and pedagogical tasks which are implemented in practical activities. Work was directed on scientific and methodological approaches to professional training of future music art teachers (system, profile, culturological, personal, competent and synergetic); separation of the conceptual ideas (integrity, complexity, national definiteness, systemacity) and their directions of the personal contents in training; definitions of conditions and the principles of activity of future music art teachers which will lead to qualitatively new level of music-pedagogical education; programming and accumulation factual material during assimilation algorithmic actions and operations in professional activity (functions, competences, forms, methods, means, ways).

This work considered:

- Indicators of experience formation of all elements of music-pedagogical activity at the beginning of the research and at the end of an experiment;

- a correction possibility of forms, methods and means during training and practice;

- improvement of theoretical and practical aspects of the method and elimination of its shortcomings of professional training process of musicians-teachers.

On a statement stage the condition of experience formation of music-pedagogical activity of future music art teachers on the basis of skilled and experimental work was defined. This stage helped us to clear the main gaps in professional activity of teachersmusicians, students in higher education institutions in 014 (Music art) profession and also allowed to specify the system's compound formation of professional experience of musicpedagogical activity of future music art teachers and to improve educational and methodical maintenance.

As a result, we found out that $6.3 \%$ of students have high level of experience in various types of music-pedagogical activity. They are capable of pedagogical and musical improvisation, interpretation of self-performing abilities, art-figurative perception and the independent analysis of the piece of music. They can make creative tasks at the high level, 
find extraordinary solutions to musical and pedagogical tasks, use traditional and innovative pedagogical approaches, originally carry out various roles (the teacher, the head of orchestra, the chorus master, the lesson director, the musicologist, the leader, etc.).

$45 \%$ of respondents have sufficient level, $24 \%$ - average, $24.7 \%$ - low. The results analysis showed that special attention in the course of professional training should be paid on creative skills formation of music-pedagogical activity in various roles (teachers, the head of orchestra, the chorus master, the lesson director, the musicologist, the compere, etc.).

The analyzed condition of experience formation of music-pedagogical activity of future music art teachers found out that the vast majority of students have sufficient $(37.5 \%)$ or average (29.6\%) level of the created study ability. $19.4 \%$ of future music art teachers showed high level. In the course of the analysis it became clear that quite significant number of students (13.5\%) of secondary education specialty (musical art) has low level of the created study abilities that has negative effect on professional training quality of future musical art teachers.

The forming stage of an experiment was directed to approbation of an author's system of experience formation of music-pedagogical activity of future music art teachers. This stage allowed to compare the level of formation of music-pedagogical activity of future music art teachers of control (further - CG) and experimental (further - EG) groups at the beginning and in the end of a forming stage of experiment. Researches allowed to clear efficiency of the carried-out work with students that receive the music art teacher profession in institutions of higher education on the basis of the offered system.

We developed and approved a set of methodical recommendations, special course "Art workshop" and tasks to it. It provides system statement of material according to new crossdisciplinary connections at conversation lectures, discussion lectures, lectures with "brainstorming" elements application, lectures with the musical and pedagogical analysis of art criticism situations, the programmed consultation lectures [5]. Practical trainings were designed to help students to realize the use of professional abilities in integrative art activity, study key concepts, consider theoretical study questions, control level of understanding of material and carry out the classwork.

The major role when forming music-pedagogical activity experience of students who studied in EG was shown by such modalities of actions as: creation of the electronic music textbook project "Music of my nation"; preparation of the flexible etude of listening to the piece of music using V. Coen technique; creation of a pantomime (a flexible miniature, a pantomime improvisation, an imitation impromptu) on certain "image" (a whimsical hare, a 
cheerful cloud, a summer rain) is defined by flexible movements, gestures, a mimicry; project implementation of multi-colored group composition ("A group tree") from florets tracery, in the each one`s center there is the photo of the fellow student, author of the work, the group curator and teachers; practices (development of lessons with computer presentations of the integrated course -"art", making crossword puzzles (schemes) on a program course subjects, creation of databases with musical themes and pieces of music for an art lesson at school, development of the multimedia presentation according to the off-hour educational scenario plan (a musical lectorium) and the educational event (a concert, etc.)); creations of a melody on the set text and its record (harmonies, the period, according to intonation hints, with rhythm and size given, in two-part form), playing a melody on specific harmony with rhythmic jazz setup etc.

Individual students work provides such methods of work as: new author's music piece sight-read, individual homework on the piece of music, individual interpretation of the piece of music, performance of its separate fragments etc. The special "Art workshop" course was introduced into professional training as the instrument of experience of music-pedagogical activity achievement which will develop complex understanding of the art phenomena in the theory and practice of the music art teacher`s work. It will teach to perceive, estimate, comprehend, reproduce works of art and the phenomena.

Noticeable percentage decrease on each criterion is worth emphasizing. So, the level of completeness, systemacy and depth of knowledge decreased from $4 \%$ in CG to $1.7 \%$ in EG on the basis of professional-pedagogical formation and innovative thinking; experience formation degree of music-pedagogical activity implementation - from $19 \%$ in CG to $9.2 \%$ in $\mathrm{EG}$; presence of emotional-aimed relation to music-pedagogical activity of future music art teachers decreased from $14 \%$ in CG to $7.9 \%$ in EG; activization of communication abilities on the basis of participants interaction of music-pedagogical activity decreased from $4.5 \%$ in $\mathrm{CG}$ to $0 \%$ in EG; level of proficiency in abilities of forecasting, analysis, control and correction of music-pedagogical activity - from $14.5 \%$ in CG to $7.5 \%$ in EG; originality of obtained creative experience in various types of music-pedagogical activity - from $24.7 \%$ in CG to $12.5 \%$ in EG. Such essential shift shows a positive trend of increasing the experience formation level of music-pedagogical activity of future music art teachers.

Conclusions. Received results demonstrate overall performance of future music art teachers`experience formation of music-pedagogical activity on the basis of the offered technique. It is found to be $23.7 \%$ of students with the high experience formation level of music-pedagogical activity. $40.7 \%$ of future music art teachers got the sufficient level, $29.1 \%$ 
are average leveled and there are 6.9\% low leveled students in EG (in CG this indicator was 13.4\%). The effectiveness of educational activity appeared in development of ability to complex comprehension of the art phenomena; in representations that separate synthetic concepts and terms in educational activity; in assimilation of theoretical and practical bases of a teaching technique of art disciplines; in ability of students to understand works of art in a complex (to perceive, estimate, comprehend); in art reflections development, art and musical memory, unique thinking of the teacher-musician; in developed abilities of music-pedagogical activity; in activization of communication on the basis of joint interaction with children at art lessons; in ability of future music art teachers to use the obtained experience in practice.

\section{Список використаних джерел:}

1. Попович, Н.М., (2015). Теорія і методика формування професійноособистісного досвіду вчителя музики в системі неперервної педагогічної освіти (автореф. дис. ... док. пед. наук: спец. 13.00.04 - теорія і методика професійної освіти). Київ, 40 с.

2. Ростовський, О.Я. (2011). Теорія і методика музичної освіти: Навч.-метод. посібник. Тернопіль: Навчальна книга-Богдан. 640 с.

3. Рудницька, О.П., (2002). Педагогіка: загальна та мистецька. Навчальний посібник. Київ: ІПППО, 270 с.

4. Хлєбнікова, О.В., (1998). Досвід музично-виконавської діяльності і діагностика його сформованості у студентів вузів культури. Київ, 18 с.

5. Чайка О.М. (2017). Інноваційна стратегія розвитку творчої самостійності студентів у процесі вивчення методики викладання зарубіжної література. Професійна підготовка фахівців: креативний підхід: монографія / за ред. О.А. Дубасенюк. Житомир: Вид. Свенюк О.О.. С.4239-449

6. Черкасов В.Ф. (2014). Теорія і методика музичної освіти. Навч. посібник. Кіровоград: РВВККДПУ ім. Винниченка. 520 с.

\section{References:}

1. Popovych, N.M. (2015). Teoriia i metodyka formuvannia profesiinoosobystisnoho dosvidu vchytelia muzyky $\mathrm{v}$ systemi neperervnoi pedahohichnoi osvity [Theory and Methodology of Formation of Professional-Personal Experience of Music Teacher in the System of Continuous Pedagogical Education] (Extended abstract of Candidate's thesis). Kyiv. [in Ukrainian]. 
2. Rostovskyi, O.Ya. (2011). Teoriia i metodyka muzychnoi osvity: Navch.metod.posibnyk [Theory and Methodology of Music Education]. Ternopil: Navchalna knyhaBohdan. 640 p. [in Ukrainian].

3. Rudnytska, O.P., (2002). Pedahohika: zahalna ta mystetska. [Pedagogy: General and Artistic]. Navchalnyi posibnyk. Kyiv: IPPPO. [in Ukrainian].

4. Khliebnikova, O.V., (1998). Dosvid muzychno-vykonavskoi diialnosti i diahnostyka yoho sformovanosti u studentiv vuziv kultury. [Experience of Music-Performing Activity and Diagnostics of its Formation in Students of Cultural Institutions]. Kyiv. [in Ukrainian].

5. Chaika O.M. (2017) Innovatsiina stratehiia rozvytku tvorchoi samostiinosti studentiv u protsesi vyvchennia metodyky vykladannia zarubizhnoi literatura. Profesiina pidhotovka fakhivtsiv: kreatyvnyi pidkhid: monohrafiia [Professional training: a creative approach] / za red. O.A. Dubaseniuk. Zhytomyr: Vyd. Yeveniuk O.O.,. pp.4239-449 [in Ukrainian].

6. Cherkasov V.F. (2014) Teoriya i metodyka muzychnoyi osvity [Theory and methodology of music education]. Navch. posibnyk. Kirovohrad: RVVKKDPU im. Vynnychenka. $520 \mathrm{p}$. 